\title{
KORELASI PERTUMBUHAN ORGAN VEGETATIF DENGAN PRODUKSI KEDELAI (Glycine max, (L) Merill)
}

\author{
Surtinah \\ Program Studi Agroteknologi Fakultas Pertanian Universitas Lancang Kuning \\ E-mail: surtinah@unilak.ac.id
}

\begin{abstract}
Abstrak
Tujuan penelitian adalah untuk menentukan organ vegetatif yang memberikan sumbangan terbaik terhadap produksi kedelai, dan melihat besarnya hubungan antara satu peubah dengan peubah lainnya dalam menghasilkan biji yang bernas, dan berat 100 biji. Penelitian ini merupakan penelitian studi literatur, dan data yang diperoleh adalah data sekunder yang dibahas berdasarkan hasil penelitian yang sudah dilakukan yang diambil dari jurnal penelitian, selanjutnya ditelaah secara deskriptif. Organ vegetatif yang berperan dalam menentukan produksi kedelai adalah tinggi tanaman, jumlah daun, luas daun, berat kering tajuk, dan berat kering akar, dan berat kering tanaman atau berat kering tajuk memiliki hubungan yang paling erat terhadap produksi biji kedelai.
\end{abstract}

Kata Kunci: Kedelai, Organ Vegetatif, Deskriptif, Peubah, Berat Kering Tajuk.

\section{PENDAHULUAN}

Kedelai merupakan salah satu bahan baku pembuat tahu, tempe, dan kecap. Dan ketiga hasil industri tersebut merupakan olahan bahan makanan yang digemari oleh masyarakat Indonesia, terutama di pulau Jawa bahan makanan olahan ini hampir ada disetiap hidangan baik di dalam keluarga maupun di acara pesta. Untuk memenuhi kebutuhan bahan baku dalam pembuatan tahu, tempe dan kecap , dan jenis olahan kedelai lainnya mencapai 2,24 juta ton setiap tahunnya (Jannah, 2011), sedangkan pasokan dari dalam negeri hanya sekitar 900.000 ton dan sisanya terpaksa harus diimpor (Anonim , 2010 dalam Charisma, Rahayu, \& Isnawati, 2012).

Peningkatan produksi kedelai dilakukan dengan berbagai cara. Salah satunya dengan melakukan penelitian. Dan penelitian yang dilakukan hampir seluruhnya bertujuan untuk meningkatkan produksi kedelai. Penelitian dilakukan dibebagai jenis tanah, seperti yang dilakukan oleh Bertham, (2002), yang membudidayakan kedelai di tanah ultisol, dan Afriyanti, Barus, \& Hasanah, (2014) dan Arinong, (2013) yang membudidayakan kedelai di lahan kering, Simanjuntak, (2005) membudidayakan kedelai di tanah sangat masam (Humitropets), Permanasari, Irfan, \& Abizar, (2014) melakukan budidaya di lahan gambut, bahkan Sri Purwaningsih (2015) melakukan penelitian di rumah kaca. Seluruh penelitian tersebut bertujuan untuk melihat pertumbuhan dan produksi kedelai.

Penelitian-penelitian lain yang

dilakukan dengan menggunakan sarana produksi seperti pupuk organik, pupuk anorganik, dan pupuk hayati juga bertujuan untuk melihat pertumbuhan dan produksi tanaman kedelai. Seperti penelitian yang dilakukan oleh Sinuraya, Barus, \& Hasanah (2015); Efendi, (2010); Sarawa, Nurmas, \& Muh. Dasril (2012); dan Marliah, Hidayat, \& Husna (2012) dengan menggunakan teknik budidaya tanaman sebagai perlakuan yaitu jarak tanam kedelai. Dan penelitian penelitian yang sudah dilakukan di atas tidak ada yang meneliti bagaimana hubungan antara organ-organ tanaman kedelai dengan produksi kedelai. Sehingga tidak diketahui seberapa besar sumbangan yang dapat diberikan oleh pertumbuhan organ tanaman kedelai terhadap produksi kedelai tersebut.

Pada umumnya peneliti mengamati jumlah cabang, tetapi tidak mengukur seberapa besar jumlah cabang akan mempengaruhi produksi kedelai. Begitu juga dengan tinggi tanaman kedelai, sebagian besar peneliti akan mengukur tinggi tanaman kedelai tetapi tidak dianalisis hubungan antara tinggi tanaman kedelai dengan produksi kedelai. Dan pada penelitian ini dilakukan analisis tentang hubungan antara pertumbuhan dengan produksi kedelai, sehingga diketahui seberapa besar 
sumbangan pertumbuhan vegetatif, dan pertumbuhan organ generatif terhadap produksi kedelai.

Tujuan penelitian adalah untuk menentukan organ vegetatif yang memberikan sumbangan terbaik terhadap produksi kedelai, dan melihat besarnya hubungan antara satu peubah dengan peubah lainnya dalam menghasilkan biji yang bernas, dan berat 100 biji.

\section{METODE PENELITIAN}

Penelitian ini merupakan penelitian studi literatur, dan data yang diperoleh adalah data sekunder yang dibahas berdasarkan hasil penelitian yang sudah dilakukan yang diambil dari jurnal penelitian, selanjutnya ditelaah secara deskriptif. Hasil dari penelitian penelitian yang menjadi sumber data, hanya menguji pengaruh perlakuan terhadap pertumbuhan dan produksi kedelai, yang menghasilkan bahwa perlakuan yang diberikan

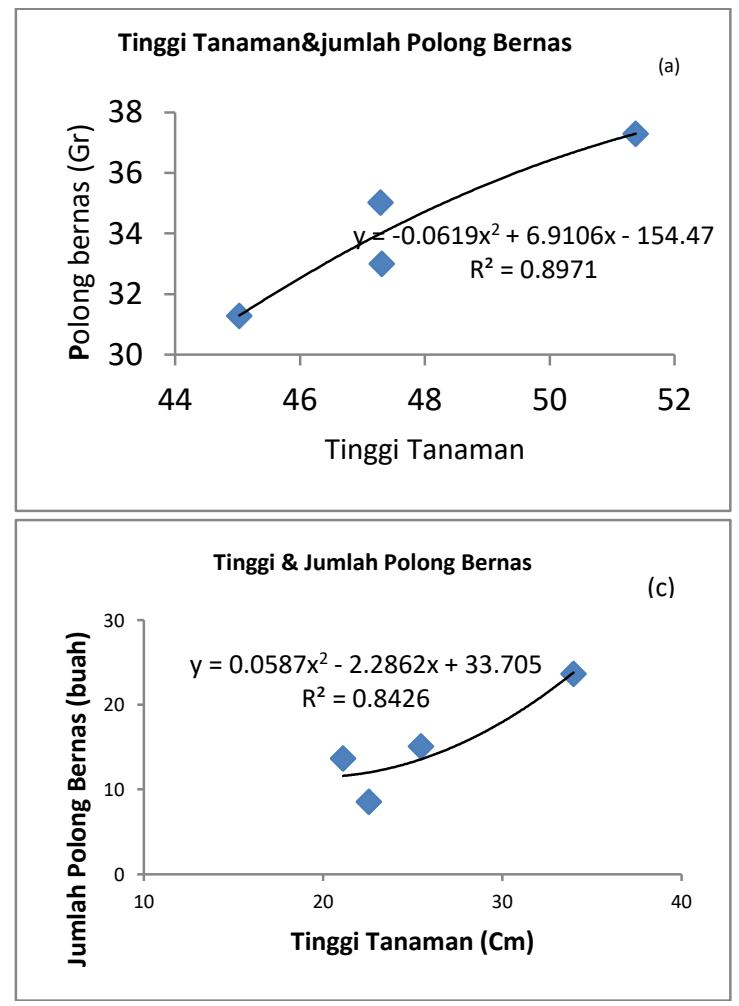

berpengaruh nyata terhadap pertumbuhan dan produksi.

\section{PEMBAHASAN}

3.1. Tinggi Tanaman

Penelitian yang dilakukan oleh Efendi (2010), melaporkan bahwa tinggi tanaman menunjukan beda nyata akibat pemberian pupuk organik lamtorogung dan pupuk kandang, ternyata bila analisis dilanjutkan dengan uji korelasi antara peubah yang diamati maka akan diperoleh suatu hubungan yang erat sekali antara tinggi tanaman dengan jumlah polong bernas, hal ini diperlihatkan dengan $\mathrm{R}^{2}=0,89$. Hal yang sama dilaporkan oleh (Simanjuntak, 2005), dimana tinggi tanaman kedelai setelah dilakukan uji korelasi menunjukan hubungan yang erat dengan berat biji bernas $\left(R^{2}=0,97\right)$, Sarawa et al., (2012) hubungan antara tinggi tanaman dengan jumlah polong bernas dengan $(\mathrm{R} 2=0,84)$ dan hasil penelitian Bertham (2002), tinggi tanaman dan berat 100 biji menghasilkan $\mathrm{R}^{2}=0,85$.

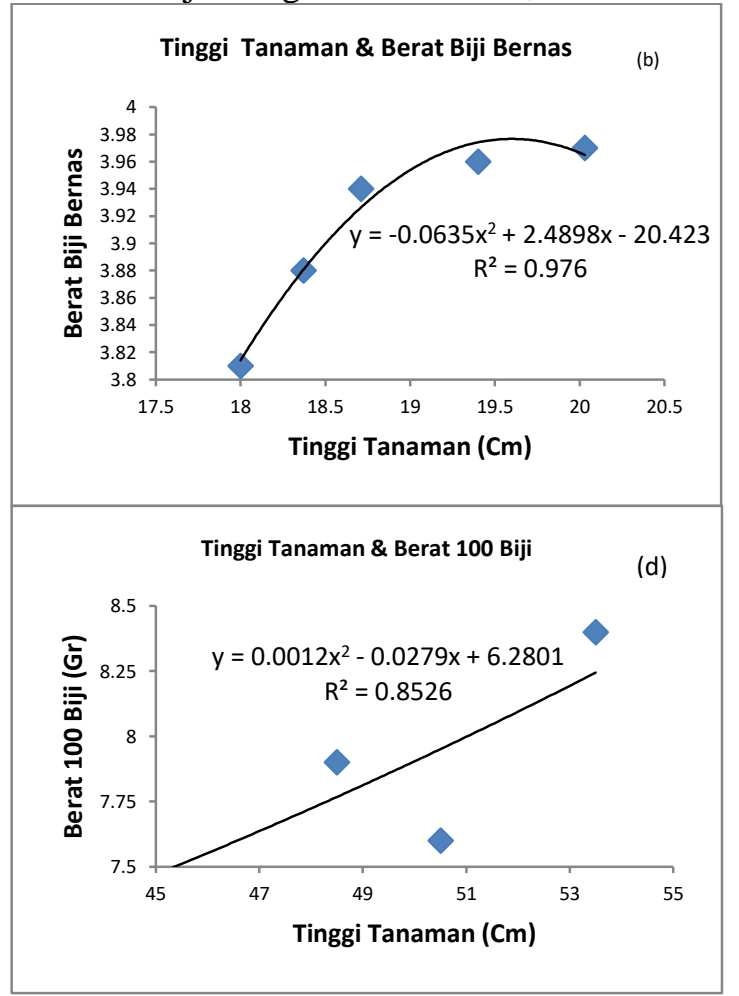

Gambar 1. Kurva hubungan antara tinggi tanaman kedelai dengan jumlah polong bernas dan berat biji bernas a. (Efendi, 2010); b. (Simanjuntak, 2005); c. (Sarawa et al., 2012); dan d. (Bertham, 2002)

Hubungan tinggi tanaman dengan produksi biji kedelai sangat erat, hal ini diduga ada hubungan dengan terbentuknya jumlah cabang produktif, semakin tinggi tanaman kedelai maka kesempatan untuk munculnya cabang produktif semakin banyak, dan dengan banyaknya cabang produktif diduga semakin banyak jumlah polong produktif, dan 
kesempatan untuk munculnya bunga akan lebih besar. Hubungan antara tinggi tanaman dengan jumlah cabang produktif dari hasil penelitian yang dilakukan oleh Simanjuntak (2005), digambarkan dengan $R^{2}=0,845$, nilai koefisien

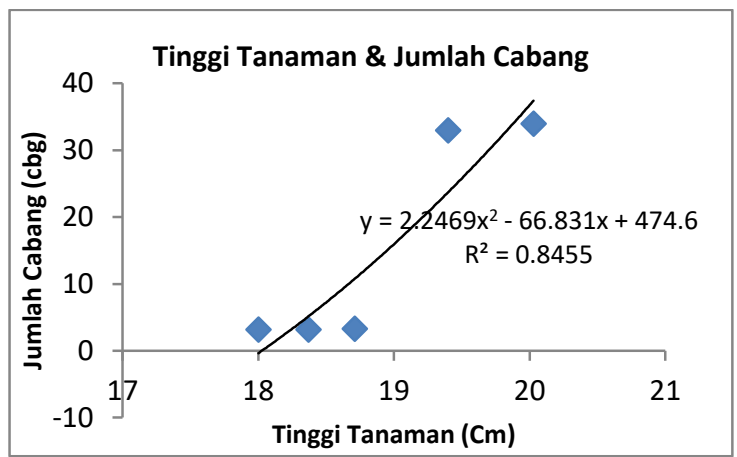

Gambar 2.Kurva hubungan antara tinggi tanaman dengan jumlah cabang produktif tanaman kedelai

\subsection{Daun}

Tanaman akan tumbuh dan berkembang dengan baik apabila daun yang dibutuhkan untuk menyediakan kebutuhan hidupnya tersedia dalam jumlah, dan ukuran yang sesuai. Tanaman kedelai dengan jumlah daun yang banyak akan memberikan pasokan asimilat yang banyak dengan syarat bahwa daun-daun tersebut mendapat intensitas yang cukup untuk melakukan proses fotosintesis. Kasifikasi tanaman kedelai secara fisiologi menggolongkan tanaman ini adalah tanaman yang masuk ke dalam golongan tanaman $\mathrm{C}_{3}$, oleh karena itu intensitas cahaya yang tinggi akan memberikan efek yang kurang baik untuk produksi biji kedelai. Tetapi bila daun tanaman sangat terlindungi, hal ini juga akan memberikan efek yang tidak baik untuk produksinya. Dari beberapa penelitian yang dijadikan acuan untuk ditelaah diperoleh hubungan antara pertumbuhan daun dengan produksi biji kedelai.

Simanjuntak (2005), melaporkan bahwa jumlah daun sangat erat hubungannya dengan berat biji kedelai, keeratan hubungan itu tercermin dar nilai $\mathrm{R}^{2}=0,956$, yang berarti bahwa $95 \%$ berat bij yang dihasilkan dapat dijelaskan oleh bertambahnya jumlah daun. regresi tersebut menunjukan keeratan hubungan antara dua variabel yang diamati. Oleh karena itu pengamatan jumlah cabang produktif pada penelitian pertumbuhan dan produksi kedelai perlu untuk diamati.

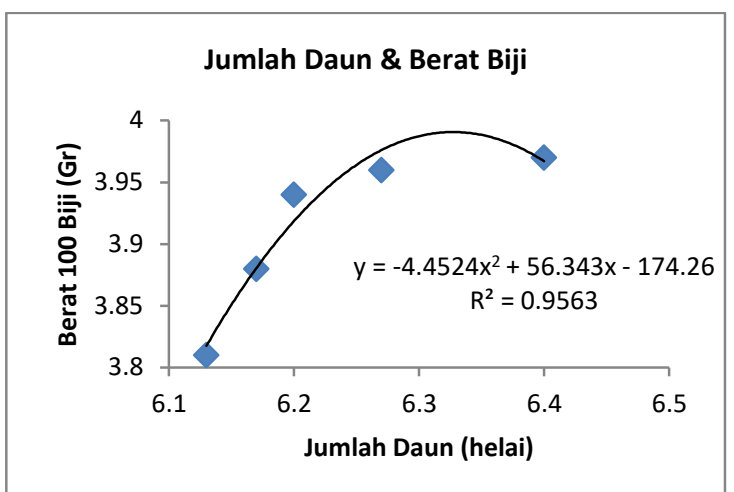

Gambar 3. Hubungan antara Jumlah daun dan Berat kering Biji kedelai

Pada penelitian yang lain (Sinuraya et al., 2015), melaporkan bahwa hubungan luas daun dengan berat 100 biji kedelai sangat erat dengan nilai koefisien regresi $=0,94$, hal ini menggambarkan semakin luas daun maka semakin berat biji kedelai tersebut. Diduga karena semakin luas daun maka permukaan daun yang menerima intensitas cahaya akan semakin luas, sehingga fotosintat yang diperoleh akan semakin banyak untuk ditranslokasikan ke biji

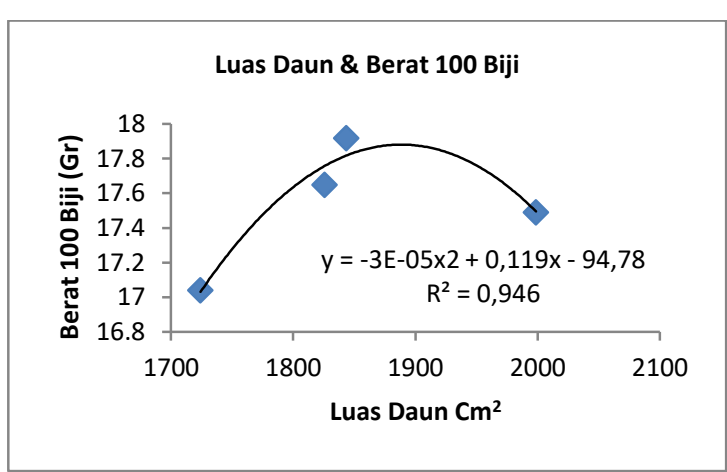

Gambar 4.Hubungan antara luas daun dengan berat kering biji

\subsection{Tajuk}

Berat kering tajuk menggambarkan jumlah sel yang terbentuk selama proses budidaya, dan pertambahan jumlah sel ini mencerminkan proses pertumbuhan tanaman kedelai berlangsung dengan baik. Hubungan berat kering tajuk dengan berat 100 biji sangat erat yang digambarkan dengan nilai $\mathrm{R}^{2}=0,91$ (Sinuraya et al., 2015). Pada akhir proses 
budidaya menunjukan jumlah berat kering yang semakin tinggi menghasilkan berat 100 biji yang semakin berat.

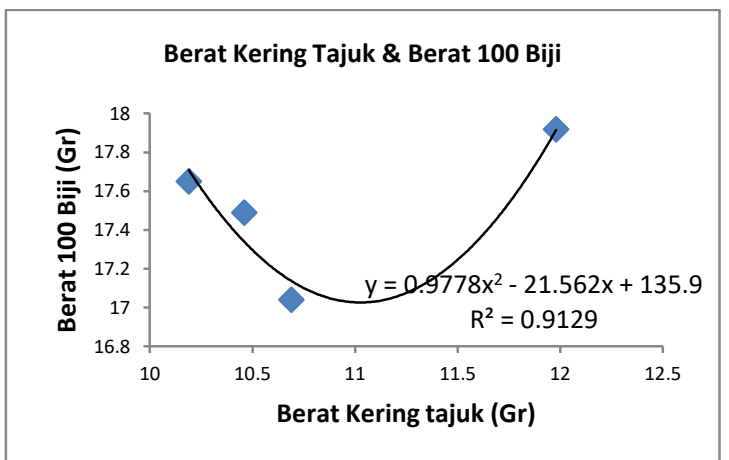

Gambar 5. Hubungan antara bert kering tajuk dengan berat 100 biji

Penelitian yang dilakukan oleh (Permanasari et al., 2014), mendapatkan bahwa hubungan antara berat kering tanaman dengan berat 100 biji digambarkan dengan nilai $\mathrm{R}^{2}=$ 0,99 , artinya bahwa berat kering tanaman terbukti memiliki hubungan yang erat dengan pembentukan biji, yang pada akhirnya akan meningkatkan berat biji kedelai. Dari kedua penelitian di atas membuktikan bahwa pengamatan terhadap berat kering tajuk tanaman kedelai juga memegang pernan penting dalam pembentukan biji kedelai. Bertambah besar berat kering tajuk maka bertambah berat biji kedelai tersebut. Hal ini menggambarkan bahwa asimilat yang terbentuk oleh tajuk yang banyak akan menambah akumulasi bahan kering ke dalam biji kedelai.

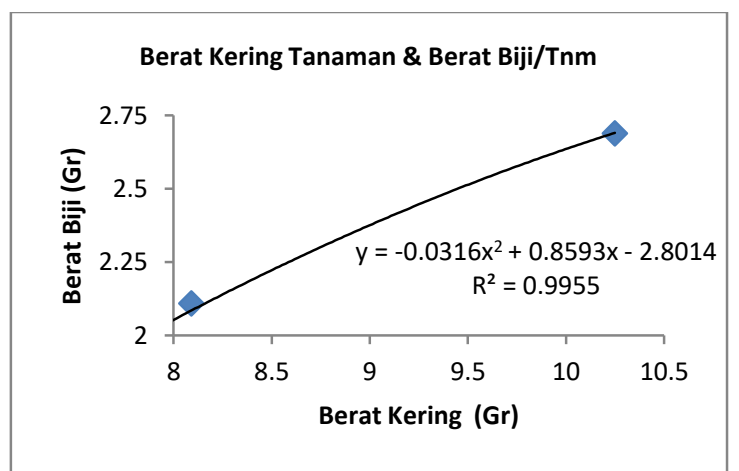

Gambar 6. Hubungan antara berat kering tanaman dengan berat biji/tanaman

\subsection{Akar}

Akar tanaman berfungsi untuk menyerap air dan unsur hara yang akan ditanslokasikan ke bagian tajuk tanaman.
Peranan akar sangat penting untuk diamati terutama penelitian-penelitian dengan memberikan perlakuan pada media tanam. Permanasari et al. (2014), melaporkan bahwa akar yang terbentuk memberikan konstribusi yang sangat baik pada proses pembentukan biji. Hal ini digambarkan pada hubungan antara berat kering akar dengan berat 100 biji kedelai yang memperlihatkan hubungan yang sangat erat sekali.

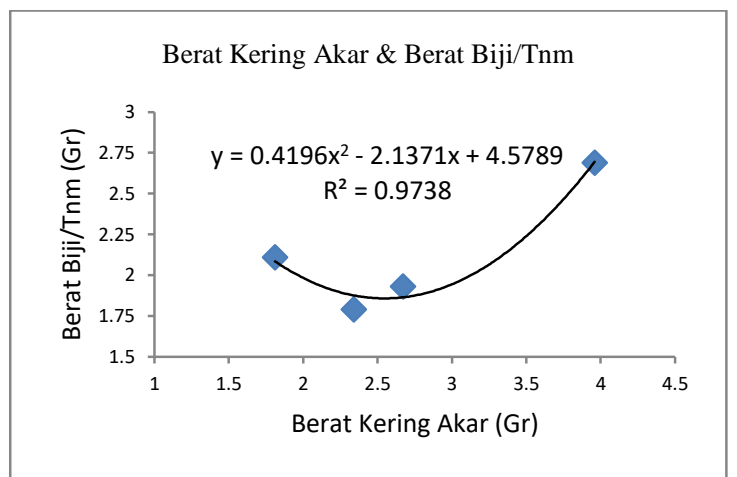

Gambar 7. Hubungan antara berat kering akar dengan berat biji/tanaman

Penelitian - penelitian yang dijadikan rujukan untuk ditelaah memberikan gambaran bahwa organ vegetatif tanaman erat kaitannya dengan akumulasi bahan kering ke dalam biji kedelai, sehingga pada saat penelitian yang mengeksploitasi tentang pengaruh perlakuan yang dikaji tidak hanya antara hubungan perlakuan dengan pertumbuhan dan produksi, tetapi kajian diperluas dengan menghubungkan antara organ vegettif dan organ generatifnya.

Begitu juga kajian antara hubungan antara organ generatif dengan produksi biji.

Pada kajian berikutnya akan ditelaah tentang hubungan umur panen dengan produksi biji kedele. Gambar 8 menunjukan bahwa semakin lama umur panen maka berat 100 biji semakin rendah, dan hubungan antara umur panen dengan berat 100 biji diperlihatkan oleh nilai $\mathrm{R}^{2}=0,88$, artinya hubungan kedua peubah tersebut erat. Dari penelitian Arinong (2013) dapat dijelaskan bahwa semakin lama biji kedelai dipanen maka bahan kering yang seharusnya terakumulasi dibiji digunakan kembali untuk proses fisiologisnya yaitu respirasi, sehingga bahan kering tersebut menjadi berkurang. Pada tanaman kedelai fotorespirasi akan terjadi bila intensitas cahaya tinggi, sehingga waktu panen yang dianjurkan 
adalah waktu panen sesuai dengan deskripsi tanaman kedelai masing-masing varistas.

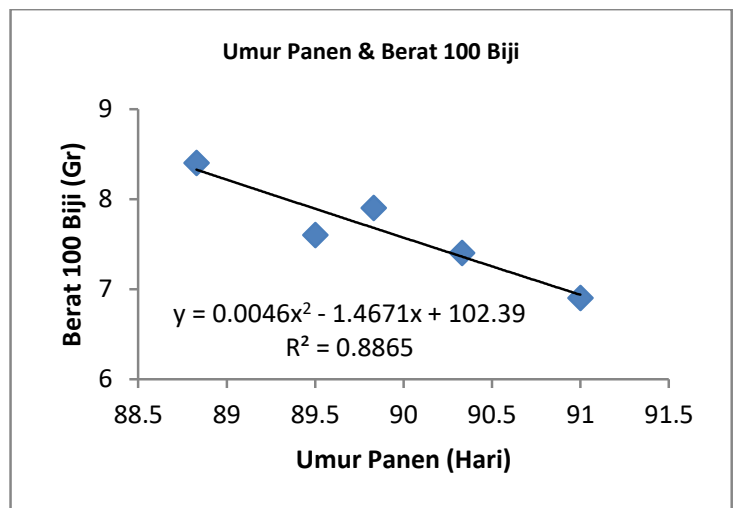

Gambar 8.Hubungan antara umur panen dengan berat 100 biji

\section{KESIMPULAN}

Hasil kajian di atas disimpulkan bahwa Organ vegetatif yang berperan dalam menentukan produksi kedelai adalah tinggi tanaman, jumlah daun, luas daun, berat kering tajuk, dan berat kering akar, dan berat kering tanaman atau berat kering tajuk memiliki hubungan yang paling erat terhadap produksi biji kedelai. Berat kering tajuk menggambarkan jumlah sel yang terbentuk selama pertumbuhan tanaman sampai berproduksi, semakin banyak sel yang terbentuk maka mencerminkan baiknya pertumbuhan tanaman kedelai tersebut yang berpengaruh terhadap produksinya. Oleh karena itu kajian terhadap hubungan pertumbuhan dan produksi perlu dijelaskan dalam suatu penelitian.

\section{DAFTAR PUSTAKA}

Afriyanti, I., Barus, A., \& Hasanah, Y. Respon Pertumbuhan dan Produksi Beberapa Varietas Kedelai (Glycine max L, Merill) di Lahan Kering terhadap Pemberian Berbegai sumber N. J. Online Agroteknologi, 2(2), 513-521. 2014

Arinong, A. R. Pertumbuhan dan produksi Kedelai dengan Pemberian Berbagai Pupuk Organik di Lahan Kering. $J$. Agrisitem, 9(2). 2013.

Bertham, R. Y. H. Respon Tanaman Kedelai (Glycine max (L), Merill) terhadap Pemupukan Fosfor dan Kompos Jerami pada Tanah Ultisol. J. Ilmu-Ilmu Pertanian Indonesia, 4(2), 74-83. 2002.
Charisma, A. M., Rahayu, Y. S., \& Isnawati. Pengaruh Kombinasi Kompos

Trichoderma dan Mikoriza Vasikular Arbuskular (MVA) terhadap Pertumbuhan Tanaman Kedelai (Glycine max (L), Merill) pada Media Tanah Kapur. J. Lentera Bio, 1(3), 111-116. 2012.

Efendi. Peningkatan Pertumbuhan dan Produksi Kedelai Melalui Kombinasi Pupuk Organik dengan Pupuk Kandang. J. Floratek, 5, 65 73. 2010.

Jannah, H. Respon Tanaman Kedelai terhadap Asosiasi Fungi Mikoriza Arbuskular di Lahan Kering. J. GaneC Swara, 5(2), 2831. 2011.

Marliah, A., Hidayat, T., \& Husna, N. Pengaruh Varietas dan Jarak Tanam terhadap Pertumbuhan Kedelai (Glycine max (L) Merill). J. Agrista, 16(1), 22-28. 2012.

Permanasari, I., Irfan, M., \& Abizar. Pertumbuhan dan Hasil Kedelai (Glycine max (L) Merill) dengan Pemberian Rhizobium dan Pupuk Urea pada Media Gambut. J. Agroteknologi, 5(1). 2014.

Sarawa, Nurmas, A., \& Muh. Dasril, A. Pertumbuhan dan Produksi Tanaman Kedelai (Glycine max L.) yang Diberi Pupuk Guano dan Mulsa Alang-alang. $J$. Agroteknos, 2(2), 97-105. 2012.

Simanjuntak, D. Peranan Trichoderma, Micoriza dan Posfat terhadap Tanaman Kedelai pada Tanah Sangat Masam (Humitropets). J. Penelitian Bidang Ilmu Pertanian, 3(1), 36-42. 2005.

Sinuraya, M. A., Barus, A., \& Hasanah, Y. Respon Pertumbuhan dan Produksi Kedelai (Glycine max (L), Merill ) terhadap Konsentrasi dan Cara Pemberian Pupuk Organi Cair. J. Online Agroteknologi, 4(1), 1721-1725. 2015.

Sri Purwaningsih. Pengaruh Inokulasi Rhizobium terhadap Pertumbuhan Tanaman Kedelai (Glycine max L) Varietas Wilis di Rumah Kaca. J. Berita Biologi, 14(1), 69-76. 2015. 